Volume 9, No.1.4, 2020

International Journal of Advanced Trends in Computer Science and Engineering

Available Online at http://www.warse.org/IJATCSE/static/pdf/file/ijatcse1391.42020.pdf

https://doi.org/10.30534/ijatcse/2020/1391.42020

\title{
Gear Ratio Optimization of Manual Transmission for Passenger Vehicle Using 1D Simulation Cycle and Statistical Analysis
}

\author{
Shaiful Fadzil Zainal Abidin ${ }^{1}$, Amir Khalid ${ }^{1 *}$, Muhammad Faris Abd Latip ${ }^{1}$, Izzarief Zahari ${ }^{2}$, Rifqi Irzuan \\ Abdul Jalal ${ }^{3}$ \\ ${ }^{1}$ Automotive and Combustion Synergies Technology Group, Faculty of Engineering Technology, Universiti Tun \\ Hussein Onn Malaysia, 84600 Pagoh, Johor, Malaysia, amirk@uthm.edu.my \\ ${ }^{2}$ Perusahaan Otomobil Nasional Sdn. Bhd. Hicom Industrial Estate, 47600 Shah Alam, Selangor, Malaysia, \\ izzarief@gmail.com \\ ${ }^{3}$ Universiti Kuala Lumpur - Malaysia France Institute (UniKL MFI), Section 14, Jalan Damai, Seksyen 14, 43650 \\ Bandar Baru Bangi, Selangor, Malaysia, rifqi@unikl.edu.my
}

\begin{abstract}
Nowadays, the global greenhouse emission becoming much worse, in lines with the increase of vehicle production which is one factor that leads to greenhouse gas emission. The properly matched engine transmission in vehicle system design is important in improving vehicle performance and fuel economy. Thus, the basic purpose of this research is to design and develop 1D vehicle physics model for powertrain matching and fuel economy prediction towards lower carbon emission vehicle and to evaluate and optimize transmission gear ratios to improve vehicle performance and fuel economy using statistical analysis. The subject of the study is a Proton Iriz 1.6L with 5 -speed manual transmission. The vehicle is modelled in GT-Suite in order to predict the vehicle performance and fuel economy. The baseline results are compared with the actual testing data with the correlation of each parameter, performance and fuel economy which resulted less than 3\% tolerance different. The optimal selection of gear ratio are determine by the Taguchi method while each gear ratio significance toward full transmission set are calculated using ANOVA. Fuel consumption is calculated through the simulation with the aid from prediction of Taguchi Method. The result gather from GT-Suite simulation shows an improvement of $1.79 \%$ for $0-100 \mathrm{~km} / \mathrm{h}$ speed and $5.56 \%$ for NEDC fuel economy compared to the baseline model. This computerize method will reduce significantly greater in real life cost, reduce the time in real testing and less computing time, also increase the productivity of the researcher and engineers
\end{abstract}

Key words : Gear ratio, Taguchi method, ANOVA, Fuel consumption, performance.

\section{INTRODUCTION}

A vehicle performance and fuel economy depend heavily on its design factor. A study in 2012 uses logistic model for fuel economy assessment prediction and exhaust emission (CO, $\mathrm{HC}$, NOx, and PM) in china and come out with conclusion that the country should develop more stringent vehicle emission standard [1-5]. An experiment in 2013 studied the performance of spark ignition (SI) engine fuelled by liquefied petroleum gas and found out that it is more practical for SI engine as its reduce on specific fuel consumption to $28.38 \%$ [6-9]. In addition, previous research used Taguchi Method for gearbox optimization which demonstrate that the Taguchi experimental techniques can effectively predict the optimum gear ratio arrangements leading to improved fuel consumption [10-11]. Meanwhile, a group of researcher proposed the computationally efficient analytical method with gear shift indicator technology approach which capable of reducing $7.5 \%$ in the brake specific fuel consumption and a reduction of $6.75 \%$ in nitrogen oxide emissions [11]. A study in 2018 studies the effect of vehicle gap changes on fuel economy and emission performance which indicate that in designing the control strategy for the ACC system can improve the stability and fuel economy [12]. Equally important experiment in 2019, coupled thermal management systems are designed which resulting the improvement of ICE fuel economy by $1.2 \%$ [13-14]. Presently, a study on the effects of butanol-gasoline blends on SI engine performance, contribute to lower $\mathrm{CO}, \mathrm{HC}$ and $\mathrm{CO}_{2}$ emission but with exception of $\mathrm{NO}_{\mathrm{x}}$ emission which much worse than that of pure gasoline [14]. Optimization of both fuel economy and performance required much time for research. Advance optimization method such numerical simulations, gear shift technology and designation of coupled thermal management systems are not efficient because the lack of facility and specialty. The method of converting conventional gasoline are also not efficient because there are some drawbacks such as requirement to redesign the engine and worsen emission 
[15]. That means the most efficient method are by taking stringent vehicle emission standard or designation of experiment to solve optimization problem. Between these methods, Taguchi method seems to be the most efficient method in terms of cost, time and manpower which already famous at many industries [16]. Taguchi method proposed a standard 8-step procedure to be applied for any process optimization as shown in Figure 1 [17-20].

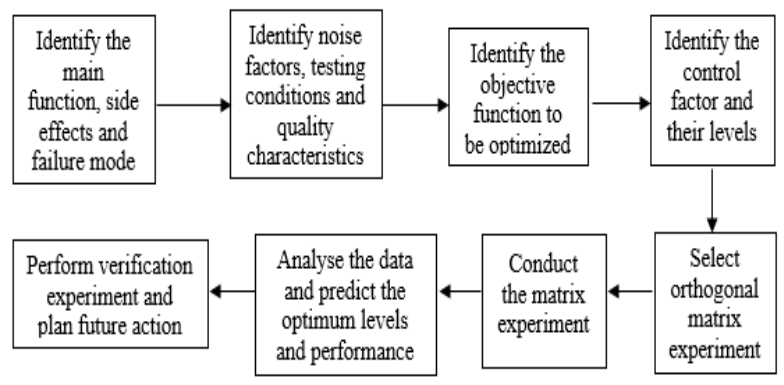

Figure 1: Taguchi method procedure

The focus on development of vehicle with lower emission is insufficient especially since there is problem regarding the cost and time. The objective of this study is to design and develop 1D vehicle physics model for powertrain matching and fuel economy for manual car towards lower carbon emission vehicle and evaluate and optimize transmission gear ratios to improved vehicle performance and fuel economy. The full vehicle model is constructed by using 1D GT-Suite simulation software. The subject of simulation is a Segment B-hatch passenger car which is Proton Iriz 1.6L. 5-speed manual transmission (5MT) will be developed and integrated with the vehicle model. The ratios will be optimized using Taguchi method to achieve fuel consumption target according to the research objective.

\section{METHOD OF RESEARCH}

The model was modelled by using a vehicle modelling software which is GT-Suite then was analyse by GT-Drive based on case study. The GT-Suite modelling was implemented to evaluate and optimize 5MT gear ratios to improve vehicle performance and fuel economy of Proton Iriz 1.6L. The results are then validated by using statistic method which are Taguchi method and analysis of variance (ANOVA) to ensure the accuracy of the result. Figure 2 shows the flow of this research.

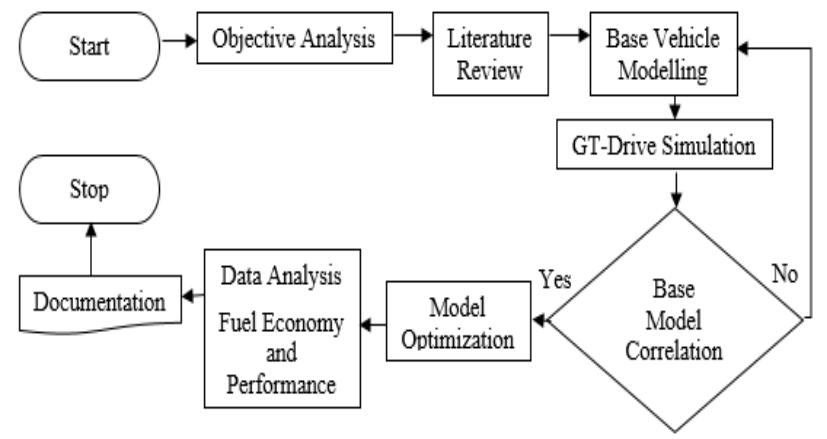

Figure 2: Method flow of research

\subsection{Driving Cycle}

To achieve accurate result on estimating fuel consumption, the experiment are conducted based on an international standard. The test are standard in many countries including Malaysia. Driving cycle is a series of data, which includes and shows the speed of vehicle versus time. The driving cycle use in this study are NEDC driving cycle. NEDC is one of driving cycle that shows the usual usage of a light duty passenger vehicle which based in Europe environment, that is last updated in 1997 and established to examine the fuel economy and emission levels. Table 1 provides the details of the drive cycle and Figure 3 shows the plot of velocity profile [21-23].

Table 1: Parameter of NEDC experiment

\begin{tabular}{|c|c|c|c|}
\hline $\begin{array}{c}\text { Distance } \\
{[\mathrm{km}]}\end{array}$ & Duration $[\mathrm{s}]$ & $\begin{array}{c}\text { Average } \\
\text { speed }[\mathrm{km} / \mathrm{h}]\end{array}$ & $\begin{array}{c}\text { Maximum } \\
\text { acceleration } \\
{\left[\mathrm{m} / \mathrm{s}^{2}\right]}\end{array}$ \\
\hline 11.02 & 1180 & 33.6 & 1.04 \\
\hline
\end{tabular}

Source: (Martini, Astorga \& De Santi, 2009)

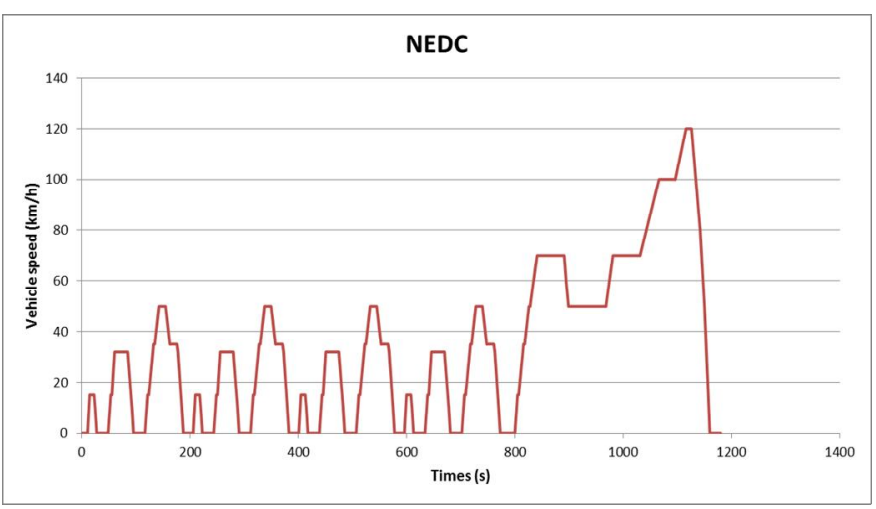

Figure 3: Velocity profile of NEDC

Source: (Martini, Astorga \& De Santi, 2009)

Table 2: Parameter of engine

\begin{tabular}{|l|c|}
\hline \multicolumn{1}{|c|}{ Parameter } & Nominal Value \\
\hline Power & Manual \\
\hline Gearbox & 15.453 \\
\hline Gear 1*Gear_diff & 8.691 \\
\hline Gear 2*Gear_diff & 5.967 \\
\hline Gear 3*Gear_diff & 4.466 \\
\hline Gear 4*Gear_diff & 3.213 \\
\hline Gear 5*Gear_diff & 3920 \\
\hline Length [mm] & 1722 \\
\hline Width [mm] & 1554 \\
\hline Height [mm] & 2555 \\
\hline Wheelbase [mm] & 155 \\
\hline Ground Clearance [mm] & 1185 \\
\hline Kerb Weight [kg] & $15 *$ x 6.5J \\
\hline Wheel Size & $185 / 55$ R15 Alloy \\
\hline Tire Size & Source: \\
\hline
\end{tabular}

Source: (Proton, 2017) 


\subsection{Vehicle Parameter}

The vehicle model that is under investigation is Proton Iriz with $1.6 \mathrm{~L}$ inline 4 cylinder natural aspirated engine. The vehicle modelling in the simulator involve feeding the input parameters for all the components in the vehicle. All the parameter are provided by Proton engineering team. This including the key information on gearbox, torque converter, clutch and brakes parameter. Table 2 shows the parameter of the tested vehicle.

\subsection{Base Model Correlation}

To simulate exactly like the real model, the simulated model must be able to produce the output which almost identical to the real model. The objective here are to determine through the NEDC and $0-100 \mathrm{~km} / \mathrm{h}$ simulation result in comparison with the real model. The tolerance of percentage different among the result must be $4 \%$ or below to ensure the simulated model simulate the same behavior as the real model when reacted with other parameter. Table 3 shows the comparison result of baseline model for the real and simulated model. Both fuel consumption and $0-100 \mathrm{~km} / \mathrm{h}$ result of simulated model are in tolerance with the real model.

Table 3: Simulation versus actual result

\begin{tabular}{|l|c|c|c|}
\hline & Simulation & Actual & $\begin{array}{c}\text { Percentage } \\
\text { Different }\end{array}$ \\
\hline $0-100 \mathrm{~km} / \mathrm{h}$ & 11.2 & 10.9 & $2.75 \%$ \\
\hline $\begin{array}{l}\text { Fuel Economy } \\
{[\mathrm{L} / 100 \mathrm{~km}]}\end{array}$ & 6.78 & 6.6 & $2.72 \%$ \\
\hline
\end{tabular}

\subsection{Designing experiment based on Taguchi Method}

Taguchi method is a powerful tool characterization, design and performance optimization. This experimental design method allows wide range of parameter, which use simple method of variation reduction. Taguchi method eliminates necessary numbers of experiment leading to cost reduction in real life experiment. This method combine statistical and mathematical method which are used in experimental studies. The optimal condition can be analyse from variation of signal-to-noise $(\mathrm{S} / \mathrm{N})$ ratio. By using this method, optimal parameters resulting in maximum sensitivity are identified. There are two factors among the parameters which are the control and noise factor. Table 4 shows the transmission setup at different level with level 3 as the base transmission setup [22].

Table 4: Transmission setup

\begin{tabular}{|l|c|c|c|c|c|}
\hline & Level 1 & Level 2 & Level 3 & Level 4 & Level 5 \\
\hline Gear 1 & 3.55 & 3.61 & 3.636 & 3.725 & 3.855 \\
\hline Gear 2 & 1.95 & 1.975 & 2.045 & 2.125 & 2.255 \\
\hline Gear 3 & 1.2 & 1.405 & 1.414 & 1.435 & 1.525 \\
\hline Gear 4 & 1 & 1.02 & 1.051 & 1.12 & 1.15 \\
\hline Gear 5 & 0.725 & 0.745 & 0.756 & 0.785 & 0.815 \\
\hline FGR & 3.85 & 4 & 4.25 & 4.5 & 4.75 \\
\hline
\end{tabular}

\section{RESULTS AND DISCUSSIONS}

By using the Taguchi method, which are orthogonal array consist of 25 rows is constructed for the controllable factors. Each row represents to the output of experiments that needs to be performed. In Taguchi method, a function which is the loss function is used to put the number of deviation from target into perspective. The loss function then are converted into a signal-to-noise $(\mathrm{S} / \mathrm{N})$ ratio. The output become a measurement tools of the impact of noise factor to the performance. S/N ratio depend heavily on experiment objective. In this study, the lower fuel consumption is the sign of good performance. So the $\mathrm{S} / \mathrm{N}$ ratio use the lower is better $\begin{array}{ccc}y_{i} & \text { (LB) for } \\ \text { Using } & \text { indicator of this respective experiment. } \\ \text { LB, the definition of the loss function (L) }\end{array}$ for fuel consumption output, of repeated experiments using different levels of noise factors is shown in equation 1

$$
L_{L B}=\frac{1}{n} \sum_{i=1}^{n} y_{i}^{2}
$$

The S/N ratio $n_{i j} \quad$ can be expressed as

$$
n_{i j}=-10 \log L_{i j}
$$

Where the $\mathrm{i}$ and $\mathrm{j}$ indices represent ith performance characteristic istic and jth experiment, respectively. Table 5 shows the number of experiment created by the Taguchi method. Each number represent the gear number for each level. Each experiment are simulated to analyse the result of NEDC and $0-100 \mathrm{~km} / \mathrm{h}$ respectively for each of the gear set given.

\subsection{Optimization based on performance}

Table 6 shows the S/N value for each gear with response to $0-100 \mathrm{~km} / \mathrm{h}$. The rank are determined by the delta amount of each level for its representative gear. The result shows that the first level of gear 1 (3.55), second level of gear 2 (1.975), the fifth level of gear $3(1,525)$, the first level of gear 4 (1.12), the fifth level of gear 5 (0.815) and differential (4.75) are the most optimum individual gear ratio for $0-100 \mathrm{~km} / \mathrm{h}$. Figure 4 shows the effect of parameters on $0-100 \mathrm{~km} / \mathrm{h}$ experiment at each gear. The graph shows each $\mathrm{S} / \mathrm{N}$ ratio for each gear ratio at each level.

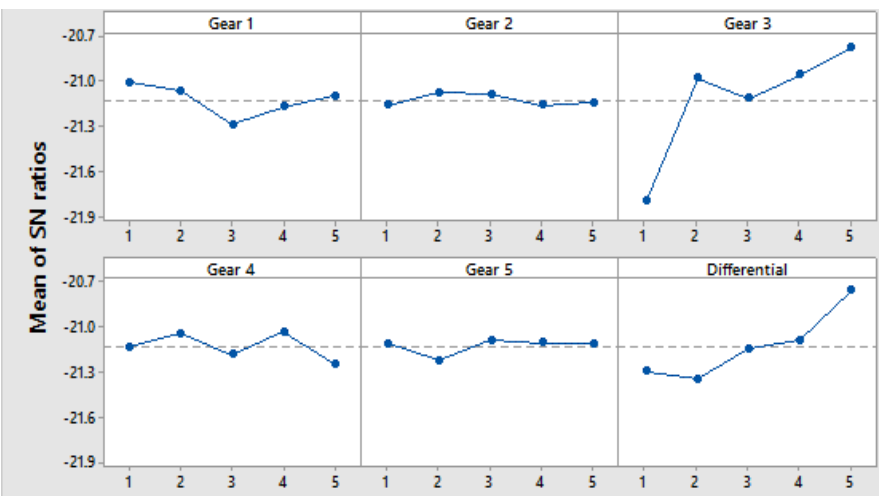

Figure 4: Main effect plot of $\mathrm{S} / \mathrm{N}$ ratio towards performance 
Table 5: Orthogonal array from Taguchi Design

\begin{tabular}{|c|c|c|c|c|c|c|c|}
\hline $\begin{array}{l}\text { Gea } \\
\mathrm{r} \quad 1 \\
\end{array}$ & $\begin{array}{r}\text { Gea } \\
\mathrm{r} \quad 2 \\
\end{array}$ & $\begin{array}{r}\text { Gea } \\
\text { r } 3 \\
\end{array}$ & $\begin{array}{r}\text { Gea } \\
\text { r } 4 \\
\end{array}$ & $\begin{array}{l}\text { Gea } \\
\text { r } 5 \\
\end{array}$ & $\begin{array}{l}\text { Differenti } \\
\text { a } 1 \\
\end{array}$ & $\begin{array}{c}\text { NED } \\
\mathrm{C} \\
\end{array}$ & $\begin{array}{lr}0-100 \mathrm{~km} \\
/\end{array}$ \\
\hline 1 & 1 & 1 & 1 & 1 & 1 & 6.2 & 12.4 \\
\hline 1 & 2 & 2 & 2 & 2 & 2 & 6.5 & 11.28 \\
\hline 1 & 3 & 3 & 3 & 3 & 3 & 6.8 & 11.21 \\
\hline 1 & 4 & 4 & 4 & 4 & 4 & 7.2 & 10.86 \\
\hline 1 & 5 & 5 & 5 & 5 & 5 & 7.7 & 10.49 \\
\hline 2 & 1 & 2 & 3 & 4 & 5 & 7.3 & 10.74 \\
\hline 2 & 2 & 3 & 4 & 5 & 1 & 6.5 & 11.3 \\
\hline 2 & 3 & 4 & 5 & 1 & 2 & 6.6 & 11.46 \\
\hline 2 & 4 & 5 & 1 & 2 & 3 & 6.8 & 11.06 \\
\hline 2 & 5 & 1 & 2 & 3 & 4 & 7 & 12 \\
\hline 3 & 1 & 3 & 5 & 2 & 4 & 7 & 11.88 \\
\hline 3 & 2 & 4 & 1 & 3 & 5 & 7.2 & 10.8 \\
\hline 3 & 3 & 5 & 2 & 4 & 1 & 6.5 & 11.18 \\
\hline 3 & 4 & 1 & 3 & 5 & 2 & 6.6 & 12.96 \\
\hline 3 & 5 & 2 & 4 & 1 & 3 & 6.8 & 11.31 \\
\hline 4 & 1 & 4 & 2 & 5 & 3 & 6.8 & 11.17 \\
\hline 4 & 2 & 5 & 3 & 1 & 4 & 7 & 10.93 \\
\hline 4 & 3 & 1 & 4 & 2 & 5 & 7.2 & 11.79 \\
\hline 4 & 4 & 2 & 5 & 3 & 1 & 6.5 & 11.63 \\
\hline 4 & 5 & 3 & 1 & 4 & 2 & 6.7 & 11.73 \\
\hline 5 & 1 & 5 & 4 & 3 & 2 & 6.6 & 11.06 \\
\hline 5 & 2 & 1 & 5 & 4 & 3 & 6.8 & 12.34 \\
\hline 5 & 3 & 2 & 1 & 5 & 4 & 7.1 & 11.05 \\
\hline 5 & 4 & 3 & 2 & 1 & 5 & 7.3 & 10.78 \\
\hline 5 & 5 & 4 & 3 & 2 & 1 & 6.6 & 11.59 \\
\hline
\end{tabular}

Table 6: $\mathrm{S} / \mathrm{N}$ value for each gear with response to $0-100 \mathrm{~km} / \mathrm{h}$

\begin{tabular}{|r|c|c|c|c|c|c|}
\hline Level & Gear 1 & Gear 2 & Gear 3 & Gear 4 & Gear 5 & Differential \\
\hline 1 & -21.01 & -21.16 & -21.79 & -21.13 & -21.11 & -21.3 \\
\hline 2 & -21.06 & -21.07 & -20.98 & -21.04 & -21.23 & -21.35 \\
\hline 3 & -21.29 & -21.09 & -21.12 & -21.18 & -21.09 & -21.14 \\
\hline 4 & -21.17 & -21.16 & -20.96 & -21.03 & -21.10 & -21.09 \\
\hline 5 & -21.1 & -21.15 & -20.78 & -21.25 & -21.11 & -20.76 \\
\hline Delta & 0.28 & 0.09 & 1.01 & 0.22 & 0.14 & 0.59 \\
\hline Rank & 3 & 6 & 1 & 4 & 5 & 2 \\
\hline
\end{tabular}

To inspect deeply on effect of each gear towards the experiment, analysis of variance (ANOVA) are used to get result. By using this method, the optimum combinations of the input parameters are more accurately determined. It also provides the percent of contribution of each gear towards the respective response, which in this scenario, the speed test. The results of ANOVA analysis, at $95 \%$ confidence interval, are shown in Table 7 and 8. Data are submitted to analyses of variance using the general linear model. The main effect terms are denoted by number of gears in table $\left(1^{\text {st }}\right.$ gears, $2^{\text {nd }}$ gear, $3^{\text {rd }}$ gear, $4^{\text {th }}$ gear, $5^{\text {th }}$ gear and differential gear assumes as a covariate). Table 7 indicates that the most significant set are the gear 3, followed by gear differential, gear 1, gear 4, gear 5 , and lastly gear 2 . The F-value are used to indicate the significant of each gear towards the experiment conducted. In ANOVA F test, by means of $F$ value, can be used to test if the estimates are significantly different using desirable confidence interval. The degree of significance of the computed $\mathrm{F}$ value can be determined by looking up $\mathrm{F}$ tables.

Table 7: Analysis of Variance

\begin{tabular}{|l|r|c|c|c|c|}
\hline Source & DF & $\begin{array}{l}\text { Adjusted } \\
\text { SS }\end{array}$ & $\begin{array}{l}\text { Adjusted } \\
\text { MS }\end{array}$ & F-Value & P-Value \\
\hline Gear 1 & 1 & 0.06845 & 0.06845 & 0.42 & 0.524 \\
\hline Gear 2 & 1 & 0.00289 & 0.00289 & 0.02 & 0.895 \\
\hline Gear 3 & 1 & 3.73738 & 3.73738 & 23.11 & 0 \\
\hline Gear 4 & 1 & 0.0409 & 0.0409 & 0.25 & 0.621 \\
\hline Gear 5 & 1 & 0.0065 & 0.0065 & 0.04 & 0.843 \\
\hline Differential & 1 & 1.53826 & 1.53826 & 9.51 & 0.006 \\
\hline Error & 18 & 2.91103 & 0.16172 & & \\
\hline Total & 24 & 8.3054 & & & \\
\hline
\end{tabular}

Table 8: Individual gear significance

\begin{tabular}{|l|c|c|c|c|}
\hline Term & Coefficient & T-Value & P-Value & VIF \\
\hline Constant & 12.561 & 29.51 & 0 & \\
\hline Gear 1 & 0.037 & 0.65 & 0.524 & 1 \\
\hline Gear 2 & 0.0076 & 0.13 & 0.895 & 1 \\
\hline Gear 3 & -0.2734 & -4.81 & 0 & 1 \\
\hline Gear 4 & 0.0286 & 0.5 & 0.621 & 1 \\
\hline Gear 5 & -0.0114 & -0.2 & 0.843 & 1 \\
\hline Differential & -0.1754 & -3.08 & 0.006 & 1 \\
\hline
\end{tabular}

Table 9 shows the final step in Taguchi method. A prediction was made by referring to Table 6 with response towards $0-100$ $\mathrm{km} / \mathrm{h}$. The value of parameter selected are the smallest value considering the experiment objective of getting lowest time achievement. The result obtains from Taguchi prediction are 10.39 seconds for $0-100 \mathrm{~km} / \mathrm{h}$. The gear settings for this experiment are shown in the table where its represent the level for each gear number. The gear ratio setting are then used in simulation to obtain the simulated result. The simulation achieve 10.5 seconds for $0-100 \mathrm{~km} / \mathrm{h}$ and 7.35 $\mathrm{L} / 100 \mathrm{~km}$ for its fuel consumption. The percentage different from base model and after the optimization are approximately $8.69 \%$ for its performance.

Table 9: Taguchi prediction

\begin{tabular}{|c|c|c|c|c|c|c|}
\hline $\begin{array}{c}\text { Predictio } \\
\mathrm{n}\end{array}$ & \multicolumn{7}{|c|}{ Settings } \\
\hline $\begin{array}{c}0-100 \\
\mathrm{~km} / \mathrm{h}\end{array}$ & Gear 1 & Gear 2 & Gear 3 & Gear 4 & Gear 5 & $\begin{array}{l}\text { Differentia } \\
1\end{array}$ \\
\hline 10.39 & 1 & 2 & 5 & 4 & 3 & 5 \\
\hline
\end{tabular}




\subsection{Optimization based on fuel economy}

For prediction towards fuel consumption, the same step as before are taken but the response are change which are towards the NEDC. Table 3.5 shows the Taguchi analysis for each gear ratio for each level. The experiment are the lower the better as the objective to get lowest fuel consumption. Based from the analysis, gear 1 at level 2 (3.61), gear 2 at level 1 (1.95), gear 3 at level 1 (1.2), gear 4 at level 1 (1), gear 5 at level 1(0.725), and differential at level 1 (3.85) are best suit transmission set for the objective. Figure 5 shows the main effect plots for signal-to-noise ratios for each gear set in response of NEDC fuel economy.

Table 10: Signal-to-noise ratio

\begin{tabular}{|c|c|c|c|c|c|c|}
\hline Level & Gear 1 & Gear 2 & Gear 3 & Gear 4 & Gear 5 & Differential \\
\hline 1 & -16.73 & -16.61 & -16.59 & -16.64 & -16.61 & -16.2 \\
\hline 2 & -16.69 & -16.64 & -16.69 & -16.67 & -16.67 & -16.39 \\
\hline 3 & -16.67 & -16.69 & -16.72 & -16.72 & -16.67 & -16.65 \\
\hline 4 & -16.7 & -16.74 & -16.75 & -16.72 & -16.77 & -16.98 \\
\hline 5 & -16.74 & -16.84 & -16.79 & -16.79 & -16.81 & -17.31 \\
\hline Delta & 0.08 & 0.23 & 0.2 & 0.15 & 0.2 & 1.11 \\
\hline Rank & 6 & 2 & 4 & 5 & 3 & 1 \\
\hline
\end{tabular}

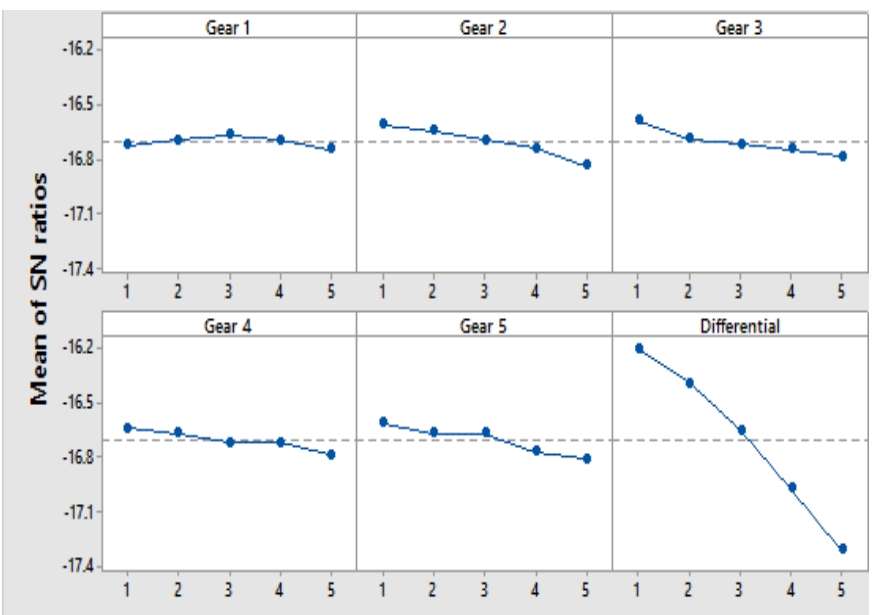

Figure 5: Main effect plot of $\mathrm{S} / \mathrm{N}$ ratio towards fuel economy

Table 11: Analysis of variance

\begin{tabular}{|l|r|c|c|c|c|}
\hline Source & DF & \multicolumn{1}{l|}{$\begin{array}{l}\text { Adjusted } \\
\text { SS }\end{array}$} & $\begin{array}{l}\text { Adjusted } \\
\text { MS }\end{array}$ & F-Value & P-Value \\
\hline Gear 1 & 1 & 0 & 0 & 0 & 1 \\
\hline Gear 2 & 1 & 0.0968 & 0.0968 & 22.51 & 0 \\
\hline Gear 3 & 1 & 0.0648 & 0.0648 & 15.07 & 0.001 \\
\hline Gear 4 & 1 & 0.0392 & 0.0392 & 9.12 & 0.007 \\
\hline Gear 5 & 1 & 0.08 & 0.08 & 18.6 & 0 \\
\hline Differential & 1 & 2.4642 & 2.4642 & 573.07 & 0 \\
\hline Error & 18 & 0.0774 & 0.0043 & & \\
\hline Total & 24 & 2.8224 & & & \\
\hline
\end{tabular}

Based on result on table 11 and 12, the most significant gear for the objective are the differential. However, differential are significant because its react with each other 5 gear set. By looking up the F-value, the most significant gear set after the differential are gear 2 followed by gear 5 , gear 3 , gear 4 and lastly gear 1 . All the result are extracted from analysis of variance (ANOVA). Table 13 shows the prediction made by Taguchi design. The gear set setting are based from the result of Taguchi analysis from Table 10. The result obtained shows the value of $6.19 \mathrm{~L} / 100 \mathrm{~km}$ for NEDC fuel consumption experiment. The settings then are used in the simulator and the result obtained are $6.22 \mathrm{~L} / 100 \mathrm{~km}$ for NEDC fuel consumption and 12.4 seconds for $0-100 \mathrm{~km} / \mathrm{h}$ test. The difference between base model and after optimization is $8.26 \%$ for NEDC fuel economy.

Table 12: Individual gear coefficient

\begin{tabular}{|l|c|c|c|c|}
\hline Term & Coefficient & T-Value & P-Value & VIF \\
\hline Constant & 5.742 & 82.74 & 0 & \\
\hline Gear 1 & 0 & 0 & 1 & 1 \\
\hline Gear 2 & 0.044 & 4.74 & 0 & 1 \\
\hline Gear 3 & 0.036 & 3.88 & 0.001 & 1 \\
\hline Gear 4 & 0.028 & 3.02 & 0.007 & 1 \\
\hline Gear 5 & 0.04 & 4.31 & 0 & 1 \\
\hline Differential & 0.222 & 23.94 & 0 & 1 \\
\hline
\end{tabular}

Table 13: Taguchi prediction

\begin{tabular}{|c|c|c|c|c|c|c|}
\hline Prediction & \multicolumn{6}{|c|}{ Settings } \\
\hline $\begin{array}{l}\text { NEDC fuel } \\
\text { consumption }\end{array}$ & $\begin{array}{l}\text { Gear } \\
1\end{array}$ & $\begin{array}{l}\text { Gear } \\
2\end{array}$ & $\begin{array}{l}\text { Gear } \\
3\end{array}$ & $\begin{array}{l}\text { Gear } \\
4\end{array}$ & $\begin{array}{l}\text { Gear } \\
5\end{array}$ & $\begin{array}{l}\text { Differen } \\
\text { tial }\end{array}$ \\
\hline 6.19 & 2 & 1 & 1 & 1 & 1 & 1 \\
\hline
\end{tabular}

\subsection{Multi response prediction}

Multi response prediction are analysis run to predict the suitable set of gear ratio with response to both $0-100 \mathrm{~km} / \mathrm{h}$ and NEDC fuel consumption. Taguchi analysis are used to determine the most suitable gear set ratio for the objective. The objective are to get lowest NEDC fuel consumption and $0-100 \mathrm{~km} / \mathrm{h}$ time achievement. To achieve the objective, the Taguchi design are set into the lower the better. Table 14 shows the Taguchi analysis towards the parameter. The selected gear set are from level 1 gear 1 (3.55), level 2 of gear 2 (1.975), level 5 of gear 3 (1.525), level 2 of gear 4 (1.02), level 3 of gear $5(0.756)$ and lastly level 1 of gear differential (3.85).

Table 14: Signal-to-noise ratio

\begin{tabular}{|r|c|c|c|c|c|c|}
\hline Level & Gear 1 & Gear 2 & Gear 3 & Gear 4 & Gear 5 & Differential \\
\hline 1 & -19.4 & -19.47 & -19.94 & -19.46 & -19.44 & -19.46 \\
\hline 2 & -19.41 & -19.41 & -19.36 & -19.39 & -19.52 & -19.55 \\
\hline 3 & -19.58 & -19.43 & -19.46 & -19.52 & -19.42 & -19.46 \\
\hline 4 & -19.49 & -19.51 & -19.35 & -19.39 & -19.47 & -19.51 \\
\hline 5 & -19.46 & -19.52 & -19.24 & -19.58 & -19.5 & -19.37 \\
\hline Delta & 0.18 & 0.11 & 0.7 & 0.19 & 0.1 & 0.17 \\
\hline Rank & 3 & 5 & 1 & 2 & 6 & 4 \\
\hline
\end{tabular}

Figure 6 shows the main effect plots for signal-to-noise ratios towards the response. There are slight diversion on each gear 
at each level except for gear 3. Table 15 shows the final prediction made at the end of Taguchi process. By using the predicted settings made by Taguchi analysis from Table 14, the final result shows that the NEDC fuel consumption are $6.44 \mathrm{~L} / 100 \mathrm{~km}$ and $0-100 \mathrm{~km} / \mathrm{h}$ speed achievement of 10.76 seconds. The setting then are used on the GT-Suite which produce the result of $6.41 \mathrm{~L} / 100 \mathrm{~km}$ for NEDC fuel consumption and 11 seconds for speed achievement on 0-100 $\mathrm{km} / \mathrm{h}$ test.

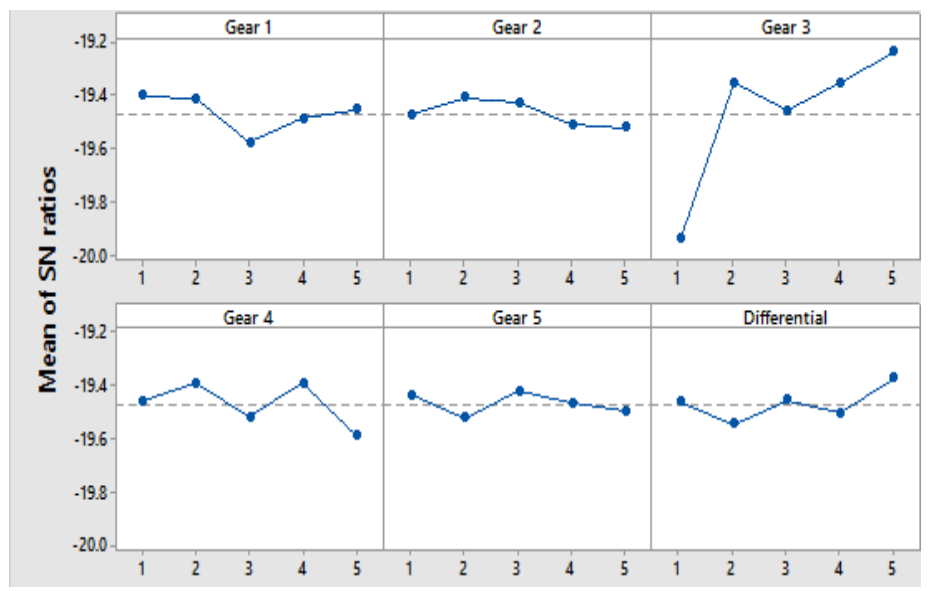

Figure 6: Main effect plot of $\mathrm{S} / \mathrm{N}$ ratio for multi response

The result gather from the experiment give the view of steps taken to achieve the relative objective. Table 16 shows the comparison result after the optimization and the base model for both Taguchi model and through GT-Suite simulation. Using Taguchi Method, the prediction resulted at 3.93\% for $0-100 \mathrm{~km} / \mathrm{h}$ speed and $5 \%$ of improvement towards NEDC fuel economy. The same transmission setup from Taguchi prediction are used in the GT-Suite to simulate the actual result. The simulation result at $1.79 \%$ for $0-100 \mathrm{~km} / \mathrm{h}$ speed and $5.56 \%$ for NEDC fuel economy compared to the base model.

Table 15: Taguchi prediction

\begin{tabular}{|c|c|c|c|c|c|c|c|}
\hline \multicolumn{2}{|c|}{ Prediction } & \multicolumn{7}{|c|}{ Settings } \\
\hline & $\begin{array}{c}0-100 \\
\text { NEDC }\end{array}$ & $\begin{array}{c}\text { Gea } \\
\text { k } / \mathrm{h}\end{array}$ & $\begin{array}{c}\text { Gea } \\
\text { r 2 }\end{array}$ & $\begin{array}{c}\text { Gea } \\
\text { r 3 }\end{array}$ & $\begin{array}{c}\text { Gea } \\
\text { r 4 }\end{array}$ & $\begin{array}{c}\text { Gea } \\
\text { r 5 }\end{array}$ & $\begin{array}{l}\text { Differentia } \\
1\end{array}$ \\
\hline 6.44 & 10.76 & 1 & 2 & 5 & 2 & 3 & 1 \\
\hline
\end{tabular}

Table 16: Result of the confirmation experiment

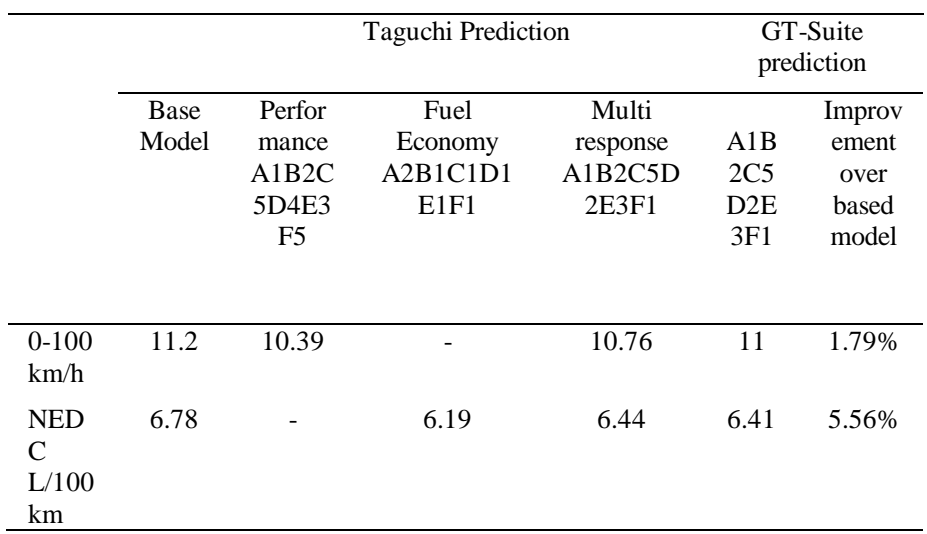

\section{CONCLUSIONS}

The research used Proton Iriz with 5MT as the subject. Gear ratio for all of the six gear including final drive in its range are divided into five levels. Using Taguchi Method, the $\mathrm{L}_{25}$ orthogonal arrays table were created. The behaviour of the subject with different combination of transmission setup are simulated using GT-Suite software and NEDC driving cycle. Fuel economy and performance are obtained for various set of transmission setup. Analysis of variance reveals that the significant factor of gear for the transmission setup are depends on cases. The optimization based on performance shows the improvement of $8.69 \%$ and optimization based on NEDC fuel consumption improve as much as $8.26 \%$ for its respective cases compared to the baseline model. Meanwhile, the result gather from multi response optimization shows an improvement of $1.79 \%$ for $0-100 \mathrm{~km} / \mathrm{h}$ speed and $5.56 \%$ for NEDC fuel economy. 1D vehicle model is successfully developed by using GT-Suite software with optimization of gear ratio are demonstrate through statistical analysis. This virtual development method with the aid from the statistical analysis will help increase the productivity of engineers and researcher, diminish time taken for bench testing and computing time, and reduce significantly greater in real life cost.

\section{ACKNOWLEDGEMENT}

The authors would like to thank the Ministry of Education Malaysia for supporting this research under Fundamental Research Grant Scheme Vot No. FRGS/1/2019/TK10/UTHM/02/10 and partially sponsored by Universiti Tun Hussein Onn Malaysia.

\section{REFERENCES}

1. Yingying Wu, P. Z. (2012, December 5). Assessment for Fuel Consumption and Exhaust Emissions of China's Vehicles: Future Trends and Policy Implications. Scientific World Journal. doi: 10.1100/2012/591343

2. Khalid, A., Nursal, R. S., Tajuddin, A. S. A., \& Hadi, S. A. (2016). Performance and emissions characteristics of alternative biodiesel fuel on small diesel engine. ARPN Journal of Engineering and Applied Sciences, 11(12), 7424-7430.

3. Khalid, A., Tajuddin, A.S.A., Jaat, N., Manshoor, B., Zaman, I., Hadi, S.A.A., Nursal, R.S.(2017). Performance and emissions of diesel engine fuelled with preheated biodiesel fuel derived from crude palm, jatropha, and waste cooking oils. International Journal of Automotive and Mechanical Engineering, 14 (2), pp. 4273-4284. DOI: 10.15282/ijame.14.2.2017.12.0341

4. Ahmad Asrul Ibrahim, Nor Azwan Mohamed Kamari, Muhammad Ammirrul Atiqi Mohd Zainuri. (2019), Optimal Scheduling of Plug-in Hybrid Electric 
Vehicles Operation in Distribution Networks Using Gravitational Search Algorithm. International Journal of Advanced Trends in Computer Science and Engineering, Volume 8, No.1.6, https://doi.org/10.30534/ijatcse/2019/3381.62019

5. Maria Charmy A. Arispe. (2020). Integrating Spatial Data Analysis for Road Traffic Incident Response System. International Journal of Advanced Trends in Computer Science and Engineering, Volume 9, No.1.2, https://doi.org/10.30534/ijatcse/2020/3291.22020

6. Ayman Taher Hindi. (2020). Design of Electronic System for Speed Detection of Vehicles. International Journal of Advanced Trends in Computer Science and Engineering, Volume 9, No.1.2.

https://doi.org/10.30534/ijatcse/2020/2791.22020

7. Khalid, A. (2013). Effect of ambient temperature and oxygen concentration on ignition and combustion process of diesel spray. Asian Journal of Scientific Research, 6(3), 434-444. doi:10.3923/ajsr.2013.434.444

8. Khalid, A., Yatsufusa, T., Miyamoto, T., Kawakami, J., \& Kidoguchi, Y. (2009). Analysis of relation between mixture formation during ignition delay period and burning process in diesel combustion. SAE Technical Papers.

9. M. Y. Sulaiman, M. (2013). Performance of Single Cylinder Spark Ignition Engine Fueled by LPG. Procedia Engineering, 53, 579-585. Retrieved 2019, from https://doi.org/10.1016/j.proeng.2013.02.074

10. Masoud Goharimanesh, A. A. (2014). More efficiency in fuel consumption using gearbox optimization based on Taguchi method. Computer Science. doi:10.1007/s40092-014-0061-y

11. Callum J Oglieve, M. M. (2017, April 26). Optimisation of the vehicle transmission and the gear-shifting strategy for the minimum fuel consumption and the minimum nitrogen oxide emissions. SAGE Journals. Retrieved 2019, from https://doi.org/10.1177\%2F0954407017702985

12. Xiuhai $\mathrm{Li}, \mathrm{T}$. Y. (2018, July 12). Effects of vehicle gap changes on fuel economy and emission performance of the traffic flow in the ACC strategy. (U. d. Mauro Villarini, Ed.)

13. Tan Tien Huynh, M. D. (2019, July). Effects of butanol-gasoline blends on SI engine performance, fuel consumption, and emission characteristics at partial engine speeds. International Journal of Energy and Environmental Engineering (4), 483-492. Retrieved 2019

14. Gequn Shu, C. H. (2019, April 2). Analysis and Optimization of Coupled Thermal Management Systems Used in Vehicles. Energies 2019. Retrieved 2019, from https://doi.org/10.3390/en12071265

15. Mecholic. (2019). LPG Advantages and Disadvantages. Retrieved 2019, from Mecholic.

16. Antony, J. (2000). Multi $\square$ response optimization in industrial experiments using Taguchi's quality loss function and principal component analysis. Quality and reliability engineering international, 16(1), 3-8.

17. Apte. (2000, August 26). TAGUCHI Methods / Robust Design / Design of Experiments. Retrieved 2019, from https://www.ee.iitb.ac.in/ apte/CV_PRA_TAGUCHI.h tm

18. Taguchi $G$ (1986) Introduction to quality engineering: designing quality into products and processes. The Organization, Tokyo.

19. Taguchi G, Yokoyama Y (1994) Taguchi methods: On-line production, vol 2. American Supplier Institute

20. Taguchi G, Elsayed EA, Hsiang TC (1989) Quality engineering in production systems. McGraw-Hill College, New York

21. BARLOW, T. J., Latham, S., McCrae, I. S., \& Boulter, P. G. (2009). A reference book of driving cycles for use in the measurement of road vehicle emissions. TRL Published Project Report.

22. Venkatesh, S. A. (2012, November). Application of Taguchi Method for Optimization of Process Parameters in Improving the Surface Roughness of Lathe Facing Operation. International Refereed Journal of Engineering and Science (IRJES), 1(3). Retrieved 2019, from http://www.irjes.com/

23. Proton. (2017). Iriz Brochure. (Proton) Retrieved May 1, 2019, from https://www.proton.com//media/project/proton-group/proton/media/car-models/i riz/brochure/iriz-brochure. ash $x$ ? la $=$ en $\&$ hash $=8119 F 00$ F6FF3B37818B3971A9C4AB477058 